特別講演 2

\title{
CONTROVERSIES IN ESOPHAGEAL SURGERY
}

David B. Skinner, M. D.

The New York Hospital-Cornell Medical Center

Currently, there are many disagreements about particular aspects of esophageal surgery. Some important controversies are discussed with reasons given for each recommendation including:

Achalasia. Long vs. short esophagomyotomy, mobilization of cardia, partial vs. total fundoplication.

Cancer.

Staging. Basis for choosing curative vs, palliative treatment.

Modifications should be made: N1 vs. N2, M1-Lym-T4.

Curative Resection. En bloc and formal lymphadenectomy, two-field vs, three-field. Stage I or II pre-op.

Palliative Resection. Esophagectomy without thoracotomy vs. standard esophagectomy, Stage III or IV pre-op. Randomized trials may not be achievable. Pre-op chemo-radiation therapy for T3N2 Stage III.

Diverticula.

Zenker's. Cricopharyngeal myotomy with diverticulopexy regardless of diverticulum size.

Epiphrenic. Esophagomyotomy onto stomach with partial fundoplication. Resection of pouch, not pexy.

特別講演 1 無血手術法

元ニューヨーク医科大学教授 廣瀬輝夫

1965年から約 18,000例の「無血手術」を施行した。 その中, 7,000余例は「工ホバ教徒」で輸血拒否の患者で あり, 他は術前, 術中, 術後,輸血不要と判断し, 他人上 りの輸血を施行しなかった症例であるが, 前者の輸血 絶対不可能の定例とは外科医の立場からは全く異なる。 輸血不可能で，しかも戒前後も自家輸血及び血没製剂投 与拒否の患者は緎細な止血之手術々式の改良が要求さ れる。外科医は麻醉師, 助手及び医療機関の協力之自身 の哲学的道德的理念の堅持が必要で「患者の疾患は治 療が可能であるが翰血を拒否するので手術不可能であ り，見殺し又は治療拒否をする」という考え方より「輸血 が出来ない可衣想な人間が疾病に羅患したのであるか ら医師はその制限内で自己の技術の最善を盡し、順応し て治療に当る」という情熱がなければならない。

25年前より無血開心術 350例を含め大諸種大手術を貣 血の為術前血色素 $3 \mathrm{gm}$ の患者数 10 例も人れて低死亡率 で施行出来た。現在エイズ, 肝炎B.C.等の不治のビール スの感染流行之翰组副作用予防の為世界的に輸血回避 及び自家輸血が取り上げられているが半分以上の輸血 は不必要である。人体生理の認識と術式改良により相当数 の輸血は避けられるので其の事について述べる。

\section{特別講演 3 甲状腺堙密の彭断と治㙩 \\ 伊藤病院 \\ 伊藤国彦}

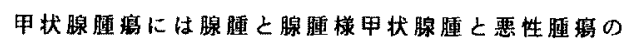

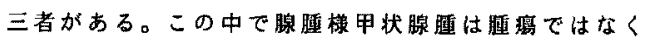
過形成である。典型的な腺腫様甲状腺腄は㮔々の变性 を伴う多発結箕性甲状腺腫であるが、单発性の腫撚と して触知されるものを腺腫棣結節と称している。腺胴 と腺腄棦結節との繿別は困難である。

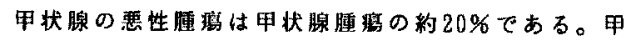

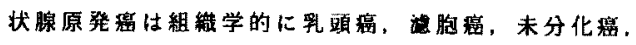

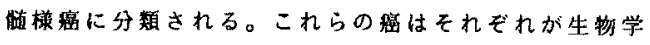
的に特性を有し，踟床像や予後も異なった特徽を有し

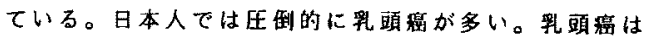
リンパ慨転移は高率であるが、発有が徐で手術成綃

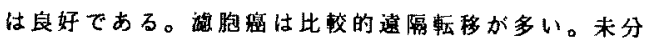

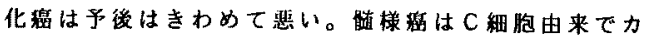
ルシトニンを分泌する。この他要性リンパ尰は近年增 加している。

甲状腺腫熄の診断には種々の画像㟝断が用いられる が，超音波部断が有用である。また等刺吸引細胞診が 診断の块め手になる。部断は良性墨性の鑑別が重要で

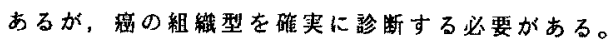

